\title{
Connexin 37 and Connexin 43 genotypes in correlation to cytokines in induced sputum and blood in cystic fibrosis (CF)
}

\author{
M Ludwig ${ }^{2}$, O Eickmeier ${ }^{3}$, C Smaczny ${ }^{3}$, F Schreiner ${ }^{1}$, W Dubois ${ }^{1}$, D NGampolo ${ }^{1}$, R Schubert ${ }^{3}$, S Zielen ${ }^{3}$, \\ R Ganschow ${ }^{1}$, S Schmitt-Grohé ${ }^{*}$
}

From 50th Workshop for Pediatric Research

Gottingen, Germany. 20-21 March 2014

\begin{abstract}
Aims
We have provided evidence in former studies that cytokines (IL-8, TNF alpha, LBP, TGFß) measured in blood correlate negatively with lung function in deltaF508 homozygous patients. GAP junction proteins might be of importance for the influx of blood cells into the lung. Our aim was to assess the relationship between connexin genotypes and cytokines (IL-8, TNF-alpha, LBP, TGFß) in induced sputum and serum, and lung disease.
\end{abstract}

\section{Methods}

36 patients homozygous for deltaF508 (median age $18 \mathrm{y}$, $\mathrm{m} / \mathrm{f} 16 / 20, \mathrm{FEV}_{1}(\%) 77$ ) were examined. Sequence analysis was performed for genes encoding GAP junction protein alpha 1 (GJA1/connexin 43) and gap junction protein alpha 4 (GJA4/connexin 37). Cytokines were assessed in serum and induced sputum (IS) by chemiluminescence (DPC Biermann, Bad Homburg, Germany) as well as leukocyte counts.

\section{Results}

DNA analysis was performed in 35 patients. Whereas GJA1 showed only one rare heterozygous synonymous SNP (rs138386744) in one patient, four common SNPs were detected in GJA4. Two were synonymous changes, but the third variant (rs41266431) predicts an amino acid substitution (GTA $\rightarrow$ valine, ATA $\rightarrow$ isoleucine) as well as the fourth SNP (rs1764391: CCC $\rightarrow$ proline, TCC $\rightarrow$ serine). For rs41266431 patients with homozygosity for the $\mathrm{G}$ variant had higher IL-8 levels (median: $13.3 / 8.0 \mathrm{pg} / \mathrm{ml}, \mathrm{p}=0.07$ ) in serum as well as leukocytes in sputum (median: $2050 / 421 / \mu \mathrm{l} \mathrm{p}=0.041$ ) than those showing heterozygosity (G/A). In individuals $>30$ years lung function (FEV1 41.3/84.83\% predicted, $\mathrm{p}=0.07$ ) was worse.

\section{Conclusion}

SNP rs41266431 seems a promising candidate for further investigations, suggesting GJA4 a potential disease modifying gene.

\section{Authors' details}

${ }^{1}$ Abt. Allgemeine Pädiatrie, Zentrum für Kinderheilkunde des Universitätsklinikums Bonn, Germany. ${ }^{2}$ Institut für klinische Chemie und klinische Pharmakologie des Universitätsklinikums Bonn, Germany. ${ }^{3}$ Christiane Herzog CF-Zentrum des Universitätsklinikum Frankfurt, Goethe-Universität, Frankfurt, Germany.

Published: 11 September 2014

doi:10.1186/2194-7791-1-S1-A11

Cite this article as: Ludwig et al:: Connexin 37 and Connexin 43 genotypes in correlation to cytokines in induced sputum and blood in cystic fibrosis (CF). Molecular and Cellular Pediatrics 2014 1(Suppl 1):A11. 